\section{Physiological Changes during Ripening of Raspberry Fruit}

\author{
Penelope Perkins-Veazie
}

U.S. Department of Agriculture-Agricultural Research Service, South

Central Agricultural Research Laboratory, Lane, OK 74555

\section{Gail Nonnecke \\ Department of Horticulture, Iowa State University, Ames, IA 50011}

Additional index words. Rubus idaeus, ethylene, nonclimacteric fruit, postharvest

Abstract. Raspberry (Rubus idaeus L., 'Heritage') fruit were harvested at six stages of color development to determine the relationship between quality attributes and physiological changes during ripening. Soluble solids concentration and fruit weight increased, whereas titratable acidity decreased during ripening. Fruit darkened and color saturation increased with maturity. Raspberry fruit exhibited a nonclimacteric pattern of respiration, and ethylene $\left(\mathrm{C}_{2} \mathrm{H}_{4}\right)$ was detected only after red pigment developed. Respiration and $\mathrm{C}_{2} \mathrm{H}_{4}$ production of whole fruit were similar to those of drupes. Ethylene-forming enzyme activity commenced in drupes and receptacle tissue from fruit at the yellow and mottled stages, respectively. These data indicate that ripening in raspberry fruit is independent of $\mathrm{C}_{2} \mathrm{H}_{4}$ production and is nonclimacteric.

Literature on the ripening patterns of small fruits often is unclear as to whether they are climacteric or nonclimacteric. Blueberries (Vaccinium corymbosum L. ) have shown a respiratory climacteric and increased $\mathrm{C}_{2} \mathrm{H}_{4}$ production coincident with ripening (Windus et al., 1976). Strawberries (Fragaria $\times$ ananassa Duch.) did not increase in respiration and $\mathrm{C}_{2} \mathrm{H}_{4}$ production during ripening (Given et al., 1988). A large increase in $\mathrm{C}_{2} \mathrm{H}_{4}$ production coincided with the transition to the last stage of color development (black to dull black) in blackberries (Rubus spp.), but the respiratory pattern was nonclimacteric (Walsh et al., 1983). Red raspberry fruit have been classified as climacteric (Blanpied, 1972; Jennings, 1988) and nonclimacteric (Kader, $1985)$ relative to color development. Ethylene emanation and internal $\mathrm{C}_{2} \mathrm{H}_{4}$ concentrations in raspberry fruit from floricanes increased as fruit color developed (Blanpied, 1972; Burden and Sexton, 1990a, 1990b). Jennings (1988) reported that respiration of floricane-produced raspberries decreased during ripening. Ethylene also was involved in fruit softening (Robbins et al., 1989a, $1989 \mathrm{~b}$ ), and abscission of raspberry drupes from the receptacle (Burden and Sexton, 1990a, 1990b).

The objective of this research was to determine the relationship between respiration, $\mathrm{C}_{2} \mathrm{H}_{4}$. production rates, and qualitative changes during ripening of raspberry fruit from primocanes.

Plant material. Fruit from 5-year-old plants of 'Heritage' raspberries were harvested every

Received for publication 28 May 1991. Accepted for publication 27 Dec. 1991. Journal Paper no. J-14493 of the Iowa Agriculture and Home Economics Experiment Station, Ames. Project no. 2808. The cost of publishing this paper was defrayed in part by the payment of page charges. Under postal regulations, this paper therefore must be hereby marked advertisement solely to indicate this fact. berry plants were grown in a primocanefruiting hedgerow at the Iowa State Univ. Horticulture Research Station, Ames, and had been sprayed weekly with recommended fungicides (Gleason et al., 1990) on a preventive schedule. Fruit of six color stages were cut with intact pedicels to minimize wounding and were transported to the laboratory. Fruit that were not used immediately were stored at $2 \mathrm{C}$. Color stages were green, yellow (yellowish drupes), mottled (yellow and red drupes), pink, red, and dark red. No symptoms of fungal decay were observed in these experiments.

Physical and chemical attributes. External color of 30 whole fruit from each color stage was measured by placing the aperature of a tristimulus color analyzer (CR200 chromameter, Minolta, Ramsey, N. J.) against each side of individual fruit. The chromameter was equipped with a strobe head having an 8mm-diameter aperature $\left(56 \mathrm{~mm}^{2}\right.$ measuring area) and was calibrated with a white standard plate $\left(\mathrm{L}^{*}=97.7, \mathrm{a}^{*}=-0.48, \mathrm{~B}^{*}\right.$ $=2.23)$. Hunter color $\left(\mathrm{L}^{*}, \mathrm{a}^{*}, \mathrm{~b}^{*}\right)$ data from the chromameter were used to calculate hue angle $\left[\tan ^{-1}(\mathrm{~b} / \mathrm{a})\right]$ and chroma $\left[\left(\mathrm{a}^{2}+\mathrm{b}^{2}\right)^{1 / 2}\right]$, as recommended for measurement of color changes in food (Hung, 1990). Hue is a measure of visible color, and chroma is a measure of brightness or intensity of the hue.

Following color determination, drupes were removed from receptacles, weighed, and homogenized in a Waring blender with distilled water $(1: 1, \mathrm{w} / \mathrm{w})$. The homogenate was filtered through four layers of cheesecloth, diluted 10-fold with distilled water, and titrated to $\mathrm{pH} 7.0$ with $0.1 \mathrm{~N} \mathrm{NaOH}$. Acidity was expressed as percent citric acid on a freshweight basis (Eaves et al., 1972). Percent soluble solids concentration (SSC) was determined on juice expressed onto a hand-held Reichert 10430 refractometer. Color, SSC, and titratable acidity (TA) were measured on three sampling dates.

Respiration and $\mathrm{C}_{2} \mathrm{H}_{4}$ determinations. Four replications of four fruit with intact pedicels (20 mm long) were used for each color stage. To prevent water stress, fruit pedicels were placed in vials containing distilled water. Two vials with two fruit per vial were placed in a 250-ml glass jar, sealed for $2 \mathrm{~h}$, and kept at 20C. Headspace gas composition $\left(\mathrm{CO}_{2}\right.$ and $\mathrm{C}_{2} \mathrm{H}_{4}$ ) was determined by injecting a $5-\mathrm{ml}$

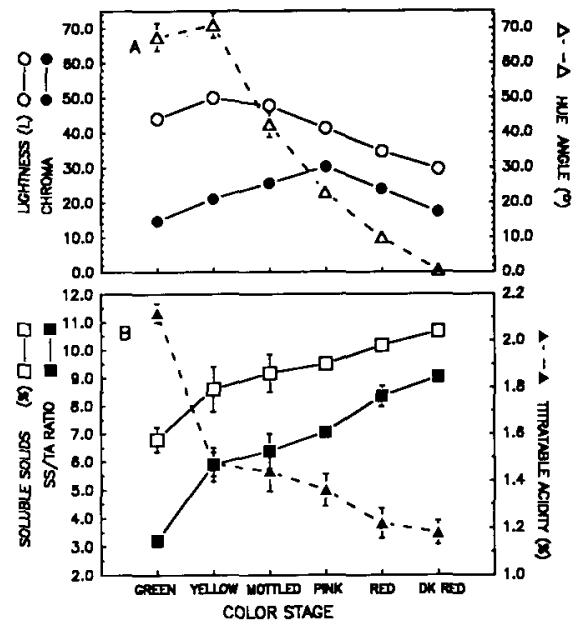

Fig. 1. Changes in color, defined as lightness, chroma, and hue (A), soluble solids concentrations (SSC), titratable acidity (TA), and SSC TA (B) in ripening raspberry fruits. Values are means of 90 fruit, $\pm \mathrm{sE}$. Error bars not visible fall within the symbol.

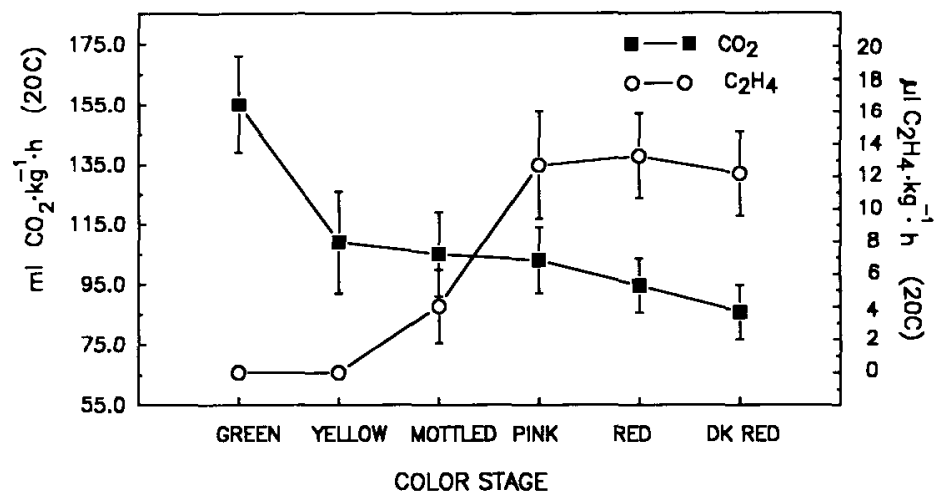

Fig. 2. Respiration rate and $\mathrm{C}_{2} \mathrm{H}_{4}$ production rates during the various stages of ripening raspberry fruit. Values represent the mean of 80 fruit, \pm sE. 

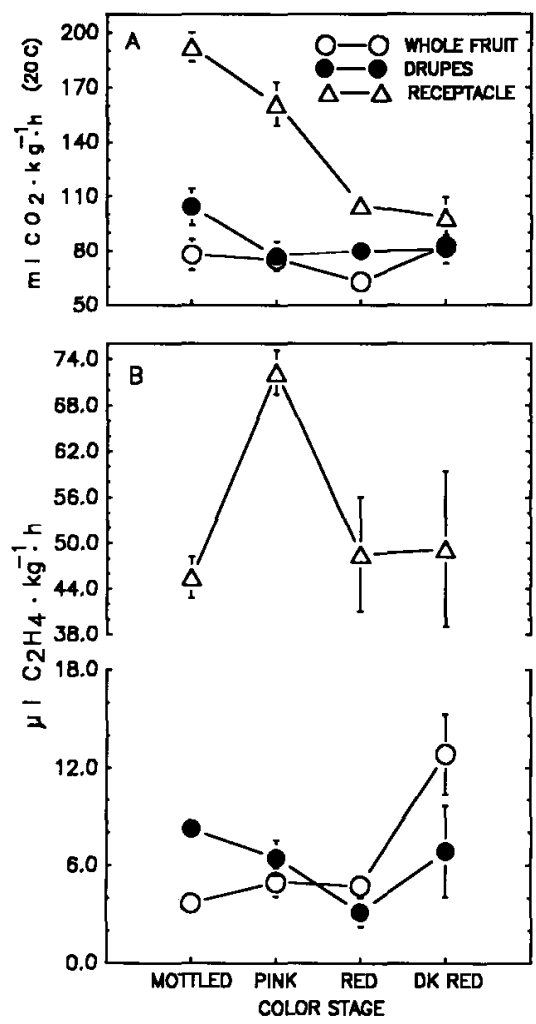

Fig. 3. Respiration rate (A) and $\mathrm{C}_{2} \mathrm{H}_{4}$ production (B) of intact fruit and of drupe and receptacle tissues of raspberry fruit. Values represent the mean of 32 fruit, $\pm \mathrm{SE}$.

sample into a stainless steel column $(3.0 \times$ $780 \mathrm{~mm}$ ) packed with Chromasorb 60/100 in a Varian gas chromatography equipped with thermal conductivity and flame ionization detectors in series. The procedure was repeated five times, each time on a different day.

To determine the contributions of the drupes and receptacle tissue to respiration and $\mathrm{C}_{2} \mathrm{H}_{4}$ production, freshly harvested fruit with pedicels were placed in vials of water, held at $2 \mathrm{C}$ overnight, rewarmed to $20 \mathrm{C}$ the next day ( $2 \mathrm{~h}$ to reach ambient temperature), and sealed for headspace analysis as described previ- ously. After headspace samples were taken from intact fruit, each drupe cap was removed from the receptacle and placed in a separate jar. Pedicels with the receptacles were kept in vials of water. Ethylene and $\mathrm{CO}_{2}$ were determined as described above. Only fruit of the mottled through dark-red stages of maturity were used for this study because drupes could be removed as an intact cap from these stages. Four replications, each of four fruit per replication, were used for each' color stage. The experiment was conducted twice using fruit from separate harvest dates.

EFE activity. Ethylene-forming enzyme (EFE) activity was determined by the method of Hoffman and Yang (1980). Separated fruit drupes and receptacles were quartered to aid penetration of the $1 \mathrm{~mm} 1$-aminocyclopropane-1 -carboxylic acid (ACC) solution. Vacuum $(78 \mathrm{~cm} \mathrm{Hg}$ ) was applied to drupe and receptacle tissue for 1 to $2 \mathrm{~min}$. Separate drupe and receptacle tissues were sealed for $4 \mathrm{~h}$ in $125-\mathrm{ml}$ Erlenmeyer flasks that contained $10 \mathrm{ml}$ of $1 \mathrm{~mm} \mathrm{ACC}$. Ethylene was determined in the headspace. Four replications (four fruit per replication) were used for each color stage, and the experiment was conducted twice using fruit from separate harvest dates.

Statistics. Data were subjected to analysis of variance. Differences between sampling dates and replications were not significant $(P<0.05)$; data averaged over sampling dates and replications are presented. Differences between maturity stages were significant $(P<0.05)$.

Quality attributes. Raspberries darkened (decreased $\mathrm{L}^{*}$ value) as they ripened (Fig. 1A). Chroma (color saturation) gradually increased as fruit ripened to the pink stage, then decreased at the later ripening stages. Hue decreased as raspberries ripened from the yellow to dark-red stage, indicating a color shift from green to red to blue-red. Similar color values were found by Robbins and Moore (1990) for fruit at the red and darkred stages. Percent SSC increased, TA decreased, and SSC : TA ratio increased as the fruit matured (Fig. 1B). These changes indicate a continuous maturation and improved

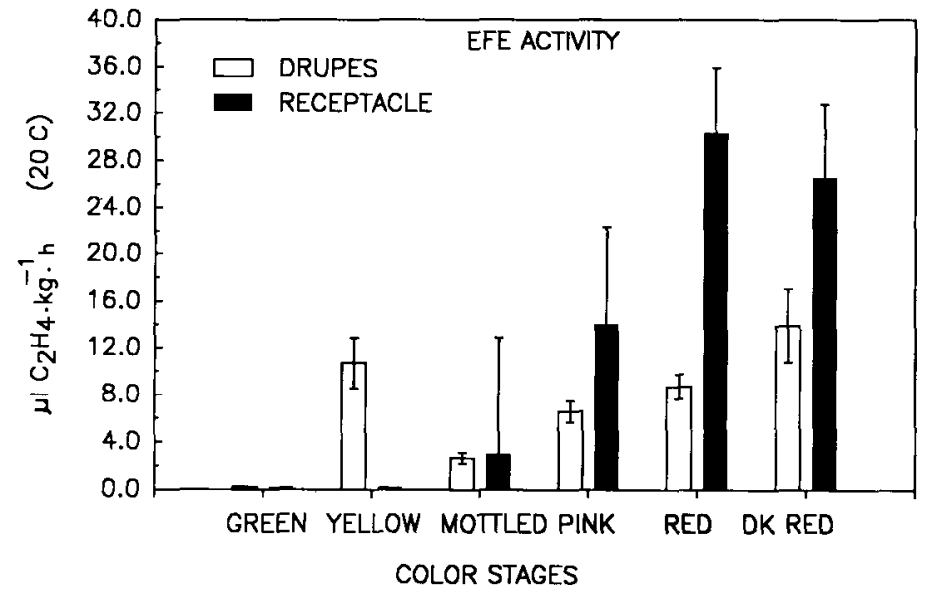

Fig. 4. Ethylene-forming enzyme (EFE) activity in raspberry drupes and receptacles as a function of maturity. Values represent the mean of 32 fruit, \pm SE. fruit quality into the dark-red stage of ripening. For mottled, pink, and red 'Heritage' fruit, SSC was slightly lower than that reported for 'Meeker' fruit at similar stages (Sjulin et al., 1989).

The declining rate of respiration as fruit ripened from green to dark red suggests that raspberry fruit are nonclimacteric (Fig. 2). No doubling in rate concomitant with color development characteristic of climacteric fruit (Biale and Young, 1981) was observed in raspberry fruit. The respiration rate for red 'Heritage' fruit was lower than that reported for 'Chilcotin', 'Meeker', or 'Willamette' fruit (Robbins et al., 1989a, 1989b). This difference may be due to the alleviation of water stress in harvested 'Heritage' fruit. Ethylene production of intact fruit was low in green and yellow fruit, higher during the transitions to mottled and pink stages, and similar to pink fruit during the transitions to red and dark-red stages (Fig. 2). Burden and Sexton (1990b) detected low levels of ethylene production at the green and yellow stages of ripening in 'Glen Cova' raspberry fruit, but production increased greatly at the mottled and later stages of ripening.

Rates of $\mathrm{CO}_{2}$ and $\mathrm{C}_{2} \mathrm{H}_{4}$ production were highest in receptacle tissue and similar for intact fruit and drupes (Fig. 3). The respiration rates of the receptacle tissue from mottled and pink fruits were higher than those of intact fruits. Receptacle tissue from red and dark-red fruits had respiration rates similar to those of intact fruits and drupes (Fig. $3 \mathrm{~A}$ ). The $\mathrm{C}_{2} \mathrm{H}_{4}$ production rates were low (3 to $8 \mu \mathrm{l} \cdot \mathrm{kg}^{-1} \cdot \mathrm{h}^{-1}$ ) for intact fruit and drupes, but were 40 times higher for detached receptacle tissues (Fig. 3B). Burden and Sexton (1990b) have suggested that $\mathrm{C}_{2} \mathrm{H}_{4}$ produced in raspberry receptacle tissue accelerates formation of the abscission zone.

Ethylene-forming enzyme activity, which can be limited by the supply of ACC and/or by the stage of ripeness (Cameron et al., 1979), was measurable at the green stage (Fig. 4). Activity was high in yellow fruit and low in mottled fruit and increased during ripening. The effect was more pronounced in receptacle than in drupe tissue.

We have found the respiratory pattern of 'Heritage' raspberry to be similar to that of other nonclimacteric fruits. Therefore, it should be classified as nonclimacteric, as defined by Biale and Young (1981). Ethylene accelerates abscission zone formation (Burden and Dexton, 1990a, 1990b) and promotes softening in raspberries (Robbins et al., 1989b). In our experiment, $\mathrm{C}_{2} \mathrm{H}_{4}$ production increased after SSC had increased and TA had decreased substantially, indicating a lack of involvement of $\mathrm{C}_{2} \mathrm{H}_{4}$ in these ripening changes.

From our data, we conclude that many of the changes in raspberry fruit associated with ripening begin at or before the yellow stage and are independent of $\mathrm{C}_{2} \mathrm{H}_{4}$ production changes. Furthermore, the pattern of $\mathrm{CO}_{2}$ production is nonclimacteric. Exogenous ethylene has been shown to induce softening and color formation in raspberry (Burden and Sexton, 1990b). The effect of exposure to 
exogenous ethylene on respiration needs to be studied to further clarify the role of ethylene in ripening of raspberries.

\section{Literature Cited}

Biale, J.B. and R.E. Young. 1981. Respiration and ripening in fruits-retrospect and prospect, p. 1-40. In: J. Friend and M.J. Rhodes (eds.). Recent advances in the biochemistry of fruits and vegetables. Academic, New York.

Blanpied, G.D. 1972. Study of ethylene in apple, red raspberry, and cherry. Plant Physiol 49:627630

Burden, J.N. and R. Sexton. 1990a. Fruit abscission and ethylene production of red raspberry cultivars. Scientia Hort. 43:95-102.

Burden, J.N. and R. Sexton. 1990b. The role of ethylene in the shedding of red raspberry fruit. Ann. Bet. 66:111-120.

Cameron, A. C., C.A.L. Fenton, Y.Yu, D.O. Adams, and S.F. Yang. 1979. Increased production of ethylene by plant tissues treated with 1aminocyclopropane-1-carboxylic acid. HortScience 14:178-180.

Eaves, C. A., C.L. Lockhart, R. Stark, and D.L. Craig. 1972. Influence of preharvest sprays of calcium salts and wax on fruit quality of red raspberry. J. Amer. Soc. Hort. Sci. 97:706 707.

Given, N. K., M.A. Venis, and D. Grierson. 1988. Hormonal regulation of ripening in the strawberry, a non-climacteric fruit. Planta 174:402406

Gleason, M., D. Lewis, G. Nonnecke, and H. Hatterman-Valenti. 1990. Iowa commercial small fruit spray guide. Iowa State Coop. Ext. Serv. Bul. Pm-1375.

Hoffman, N.E. and S.F. Yang. 1980. Changes of 1-aminocyclopropane-1-carboxylicacidcontents in ripe.ning fruits in relation to their ethylene production rates. J. Amer. Soc. Hort. Sci. 105:492-495.

Hung, Y-C. 1990. Effect of curvature and surface area on calorimeter readings - a model study. J. Food Quality 13:259-269.

Jennings, D.L. 1988. Raspberries and blackberries: their breeding, diseases and growth. Academic, New York.

Kader, A.A. 1985. Postharvest biology and technology, an overview. Postharvest technology of horticultural crops. Coop. Ext. Univ. of California, Div. Agri. and Natural Resources. Spec. Publ. 3311. p. 3-11.

Robbins J. and P.P. Moore. 1990. Color change in fresh raspberry fruit stored at $0,4.5$, or $20 \mathrm{C}$. HortScience 25:1623-1624.

Robbins, J., P.P. Moore, and M. Patterson. 1989a. Fruit respiration rates and firmness of red raspberry and related Rubus genotypes. Acts Hort. 262:311-317.

Robbins, J., T.M. Sjulin, and M. Patterson. 1989b. Postharvest storage characteristics and respiration rates in five cultivars of red raspberry. HortScience 24:980-982.

Sjulin, T.M. and J. Robbins. 1987. Effects of maturity, harvest date, and storage time on postharvest quality of red raspberry fruit. J. Amer. Soc. Hort. Sci. 112:481-487.

Walsh, C. S., J. Popenoe, and T. Solomos. 1983. Thornless blackberry is a climacteric fruit. HortScience 18:482-483.

Windus, N. D., V.G. Shutak, and R.E. Gough. 1976. $\mathrm{CO}_{2}$ and $\mathrm{C}_{2} \mathrm{H}_{4}$. evolution by highbush blueberry fruit. HortScience 11:515-517. 